\title{
DIVERSITY OF ANTS (HYMENOPTERA: FORMICIDAE) INSIDE AND OUTSIDE HIVES OF THE WESTERN HONEY BEE APIS MELLIFERA L. (HYMENOPTERA: APIDAE), JUJUY, ARGENTINA
}

\author{
Gisela Beatriz Ruiz" ${ }^{12 *}$ and Marcelo Benítez Ahrendts ${ }^{1,2}$ \\ ${ }^{1}$ Instituto de Ecorregiones Andinas (INECOA)-Consejo Nacional de Investigaciones Científicas y \\ Técnicas (CONICET), Avenida Bolivia 1239, San Salvador de Jujuy, Jujuy,Argentina. \\ ${ }^{2}$ Laboratorio de Microbiología y Sanidad Apícola, Facultad de Ciencias Agrarias, Universidad Nacional \\ de Jujuy, Alberdi 47, San Salvador de Jujuy, Jujuy, Argentina; mrba71@yahoo.com.ar \\ *Corresponding author E-mail: gisela574@gmail.com
}

\begin{abstract}
Ants are frequent visitors to Apis mellifera L. hives. Certain species may cause serious loss of productivity to apiculture. The objective of this study was to describe the diversity and abundance of ants both outside and inside the hives of Apis mellifera L. in Valles Templados, Jujuy province, Argentine. Ants were collected by hand and pitfall traps in the Spring and Summer season of 2016, 2017 and 2018, in apiaries found at three different localities of Valles Templados: Río Blanco, Tilquiza and Severino. Pitfall trapping resulted in 824 specimens belonging to 10 species in Severino, 208 individuals of 9 species in Tilquiza, and 289 individuals of 2 species in Río Blanco. The most common ant species found were: Pheidole sp. (56.07\%), Linepithema humile $(94.81 \%)$, and Solenopsis sp. $(56.73 \%)$ in Severino, Rio Blanco and Tilquiza, respectively. The hand collection of ants yielded 248 individuals of 7 species collected in Severino, 35 individuals of 3 species in Tilquiza, and 294 individuals of 2 species in Río Blanco. The most common species was Linepithema humile $67.3 \%$. The abundance figures showed significant differences among sampling sites. Several species collected by hand were the same as those collected with pitfall traps at the three localities. This study provides information about the taxonomic composition of Formicidae associated with Apis mellifera L. in Valles Templados in Jujuy. It also provides valuable information on the effect of ants on bee hives, which enables to develop control measures where necessary.
\end{abstract}

Key words: ants, bee, Pheidole sp., Linepithema humile, Solenopsis sp., Apis mellifera L, diversity, hives.

\section{INTRODUCTION}

Argentina has the largest and most welldeveloped apicultural industry in the whole Southern hemisphere and one of the biggest in the world. Around 4,000,000 hives and 35,000 registered producers contribute to more than $20 \%$ of world exports (Ferrari et al., 2011). Healthy bees have habits that promote hive hygiene, which prevents certain diseases or the action of parasites and arthropod predators (Dini and Bedascarrasbure, 2011).
Dead bees, mummified larvae (due to mycoses) and other evidences that bees have been attacked can be detected by observing the ground below and in front of the hives (BenítezAhrendts et al., 2015). In fact, there are many predators that can reduce and exterminate bee colonies. Among them are several species of ants and wasps (Guzmán et al., 2011). Ants can sometimes wander or nest inside the hives, taking advantage of the warm and humid environment inside. However, not all species are harmful to bees. The main problem with ants nesting inside

Received: 11 November 2019. Accepted: 02 January 2020. 
hives is the inconvenience for beekeepers when examining the hives (Valega, 2016). A previous study carried out in Valles Templados (province of Jujuy, Argentina) concluded that the ant species found inside and around the hives were not harmful to bees (Ruiz and Benítez, 2018).

Ants belonging to the Pheidole species are abundant and prevail in warm-climate places, especially in leaf litter and soil, feeding on other insects or wandering in search of sugary substances (Longino and Cox, 2009). Solenopsis sp. invades different ecosystems, including urban areas, feeding mainly on young plants, seeds and insects, and attacking small animals. Solenopsis sp. ants usually build their nests under wood, branches, and others (GISD, 2019). Some genera of Acromyrmex that constitute the group of the "superior Attini" are known as leaf cutter, pruning or farming ants. They feed on fungi, which grow on leaf segments that they cut, and nest preferably in sandy soils (Culebra-Mason, 2009; Nobua Behrmann, 2014). They have the ability to find the best path between their food sources and nests traced with organic products that they emit (Anglada et al., 2013). Crematogaster $\mathrm{sp}$. is found in different tropical regions of the world and in the Neotropical region (Blaimer, 2012b). Its numerous species are generalist fodders, forming small colonies under the loose bark of trees or in dry wood (Hosoishi, 2015). Linepithema humile is found nesting under fallen and partially excavated logs. It is an annoying species in households, as it invades pantries and other places in search of sweet substances. In general, it is recognized as a generalist forage and common soil inhabitant (Merrill et al., 2018). Workers sometimes steal honey from the hives of young bees, recently installed, and compete with them for the sources of nectar. Their small size means that they can not be attacked by guardian bees to drive the sting (Ruiz and Benítez, 2018). Pachycondyla sp. can be found in both humid, dry forests and savanna areas. The genus has a cosmopolitan distribution. They build their nests on the ground, leaf litter or rotten wood on the ground. All are predators and a few are generalists (Lattke, 2003). Ants belonging to the Camponotus genus show omnivorous habits, and usually feed on the sugary secretions of aphids and other arthropods. They are known as carpenter ants, and live in hollow trunks. They form colonies of different magnitudes in the soil, bases or canopies of trees (EcuRed, 2017). Finally, Pseudomyrmex sp. ants live in the arboreal stratum, where they nest inside dead branches or in modified thorns of myrmecophile plants. They are common in tropical moist forests, but they can also be found in savannahs and cold regions (Ward, 2017).
Previous studies have described Linepithema humile as harmful to beekeeping due to honey theft and displacement of bees, which weakens hives and causes a negative impact on the efficiency of pollination and productivity of bees (Jones et al., 2016). However, this species also acts as a potential mechanical vector of pathogenic microorganisms (Ipinza-Regla et al., 1984, IpinzaRegla et al., 2015). The Pheidole species is very attracted to honey, and has also been described as harmful to bees (Moreno-Moreno y MezaSantacruz, 1970). Due to its invasive nature, Solenopsis sp. can displace and kill bees from weak and/or dying beehives (Ruiz and Benítez, 2018). Ants are highly adaptable and some species are anthropophilic. In fact, they play an important role as their activity contributes to shape the structures of plant communities and those of other organisms (Lach, 2010). The diversity analysis can determine the taxonomy, preservation of these organisms, as well as the structure and functioning of these communities of insects (Garcia et al., 2013).

The objective of this study was to describe the diversity of ants found outside and inside the hives of Apis mellifera L. in Valles Templados, Jujuy province, Argentina. To our knowledge, this is the first study on this topic and will allow for the identification, management and control of ant species that can be harmful to beekeeping.

\section{MATERIALS AND METHODS}

\section{Locations}

The study was conducted in apiaries located in Severino (24⒊ $34^{\prime} 97^{\prime \prime}$ S; 65 $\left.5^{\circ} 19^{\prime} 33^{\prime \prime} \mathrm{W}\right)$, Tilquiza $\left(24^{\circ} 05^{\prime} \mathrm{S} ; 65^{\circ} 17^{\prime} \mathrm{W}\right)$ and Rio Blanco $\left(64^{\circ} 13^{\prime} 0.04^{\prime \prime}\right.$ S; 65⒈'54.1' W), Valles Templados (Jujuy province), which includes Dr. Manuel Belgrano, Palpalá, El Carmen and San Antonio departments (Buitrago 1999). This region belongs to the Chaco phytogeographic province, which occupies the plain areas and low hills of the southeast of the province, forming wide ecotones or transition areas with Las Yungas rainforest (Cabrera, 1982).

The natural flora consists of a transitional wood ("Yungas-chaco"), dominated by xerophytic components, with plenty of bushes, cacti and spiny bromeliads. The climate is highland subtropical, mild, with a barren season and rainfall concentrated in summer. Winters are cool, while summer temperatures are mild to moderate; autumns vary from mild to cool and springs are hot. Environmental mismanagement in this region is common. The warmest months record an average temperature of $20^{\circ} \mathrm{C}$, while the coldest months reach an average of $11^{\circ} \mathrm{C}$; temperature variation is explained by an average 
altitude of 1,100 m.a.s.l. Average rainfall reaches up to $1000 \mathrm{~mm}$ per year (Braun 2001). Unlike Severino and Tilquiza, Rio Blanco shows a gradual increase in urban population, with numerous industrial activities and commercial establishments (Carrillo and Londero, 2016).

\section{Sample collection}

Sampling was carried out near apiaries belonging to the Cooperativa de Productores Apícolas de Jujuy Ltda. (COPAJ) in Río Blanco, Tilquiza and Severino (Valles Templados of Jujuy, Argentina) during 2016, 2017 and 2018. Hand collection of ants inside the hives was performed with tweezers and brushes. All surface areas were carefully examined, including the outer roof cover, inner roof cover, honey chamber, brood area of the hive and hive baseboard or floor, during the three years of sampling. Ants were sampled from an average of twelve hives during the rainy season (summer), and ten beehives in the dry season (spring) at the three localities. The samples taken during the three years of study often belonged to different hives. In general, the ants were not established in the same hives. Before ants were collected, their activity (the route they made, what they collected and took, where they stayed, their reaction to bees, etc.) was observed and recorded in the morning and afternoon hours.

Pitfall traps were placed for three years at a distance no greater than 3 meters around the hives studied in the dry and rainy seasons. Four pitfall traps were set up per apiary with three replicas. Ant samples were preserved in $96 \%$ ethanol, labelled and taken to the Laboratory of Microbiology and Beekeeping Health of the Agrarian Faculty, National University of Jujuy, Argentina, where they were identified by means of a stereomicroscope (40X maximum magnification), and with different identification keys (Kuznezov 1952; Mackay and Mackay, 2002; Blaimer, 2012a; Olivero et al., 2009). Finally, the samples were placed in the entomology collection of the Instituto de Biología de las Alturas (INBIAL) of the National University of Jujuy.

\section{Data analysis \\ $\alpha$ diversity measurement}

The community characteristics assessed were: Species Richness (S), Abundance (N), Shannon Index $(\mathrm{H})$ and Dominance (D), according to the methodology describe by Moreno (2001). Species Richness (S) corresponds to the total number of species obtained by means of a community census. Relative abundance $(\mathrm{N})$ corresponds to the percentage of individuals of a particular taxon in relation to the total number of individuals in the community. Shannon Index $(\mathrm{H})$ reflects the homogeneity. The more uniform the distribution of the taxa that made up the assembly the greater the value obtained. Finally, dominance indexes (D) consider the best represented taxon and this, in particular, shows the probability that two individuals chosen at random belong to the same taxon (Moreno, 2001).

\section{$\beta$ diversity measurement}

The three study sites were compared in order to determine similarities in taxonomic composition by means of the Jaccard similarity index. This coefficient can be obtained based on qualitative data ranging from 0 (when sites do not share the same species) to 1 (when sites share the same species) (Moreno, 2001; Carmona and Carmona, 2013).

$\alpha$ and $\beta$ diversity measurements were estimated using PAST software (Hammer et al., 2001). Default settings were used for the analyses, based on the abundance data at the three localities.

The abundance data of the sampling sites did not respond to a normal distribution according to the Shapiro Wilks test ( $p \geq 0.05, p=0.0001)$, so they were compared using the nonparametric variance analysis of Kruskal Wallis (Di Rienzo et al., 2015). This analysis determined whether the diversity of ants between the sampling sites showed significant differences. In addition, a statistical analysis was conducted to determine if species abundance of each site showed significant differences during the three years of sampling. The tested factors were species abundance, sites and years of sampling.

\section{RESULTS}

\section{$\alpha$ diversity measurement}

The records of Richness, Abundance, Dominance, and Shannon Diversity can be seen in Table 1 and Table 2. Severino had the highest ant species diversity and abundance indexes in the pitfall traps (824 ants belonging to 10 species), followed by Rio Blanco (289 ants belonging to 2 species) and Tilquiza (208 ants belonging to 9). Pheidole spp. ants $(56.07 \%)$ were dominant in pitfalls in Severino, while Solenopsis spp. ants $(56.73 \%)$ were dominant in Tilquiza. Rio Blanco recorded the highest dominance index with Linepithema humile, which accounted for $94.81 \%$ of the pitfall catch.

The Kruskal Wallis statistical test was performed using the Infostat program. Significant differences $(p \geq 0.05 ; p=0.001 ; g 12)$ were observed between the sampling sites in terms of ant diversity. Severino and Tilquiza shared similar characteristics, while Rio Blanco had different 
Table 1. $\alpha$ diversity indexes of ant obtained with pitfalls traps in apiaries at Severino, Tilquiza and Rio Blanco localities, Jujuy, Argentina.

\begin{tabular}{lccc}
\hline $\begin{array}{l}\text { Locality } \\
\alpha \text { diversity indexes }\end{array}$ & Severino & Tilquiza & Rio Blanco \\
\hline Richness & 10 & 9 & 2 \\
Abundance & 824 & 208 & 289 \\
Dominance & 0.3452 & 0.4164 & 0.9016 \\
Diversity of Shannon & 1.544 & 1.129 & 0.2041 \\
\hline
\end{tabular}

Table 2. Relative abundance (\%) of ant species obtained with pitfall traps in apiaries at Severino, Tilquiza and Rio Blanco localities. Jujuy, Argentina.

\begin{tabular}{lccc}
\hline \multicolumn{1}{c}{ Locality } & Severino & Tilquiza & Rio Blanco \\
Species & & & \\
\hline Myrmicinae & 56.07 & 29.81 & 0 \\
$\quad$ Pheidole sp. & 0.12 & 56.73 & 0 \\
$\quad$ Solenopsis sp. & 8.37 & 0.48 & 0 \\
$\quad$ Acromyrmex hispidus & 2.79 & 1.92 & 0 \\
$\quad$ Crematogaster sp. & 10.92 & 4.33 & 94.81 \\
$\begin{array}{l}\text { Dolichoderinae } \\
\text { Linepithema humile }\end{array}$ & & & \\
Ponerinae & 3.03 & 0.96 & 0 \\
$\quad$ Pachycondyla constricta & 5.70 & 5.77 & 5.19 \\
$\begin{array}{l}\text { Formicinae } \\
\text { Camponotus mus }\end{array} \quad$ Camponotus punctulatus & 7.28 & 0 & 0 \\
$\quad$ Camponotus substitutus & 3.40 & 0 & 0 \\
Pseudomyrmicinae & & & 100 \\
$\quad$ Pseudomyrmex sp. & 2.31 & 0 & \\
Total & 100 & 100 & \\
\hline
\end{tabular}

characteristics. Each study site maintained approximately the same species abundance and diversity during the three years of sampling, with no significant differences $(p \geq 0.05 ; p=0.433 ; g 18)$ between the sampling periods for each locality.

Hand collection inside the hives yielded six species in Severino, three species in Tilquiza and two species in Rio Blanco. Linepithema humile was the most commonly found species. This coincides with the data obtained from pitfall trapping (Table 3).

\section{$\beta$ diversity measurement}

Tilquiza and Severino showed a higher similarity index (0.7), and therefore they were classified in a group. Río Blanco recorded the lowest similarity index value $(<0.3)$. The value close to 1 shows that Tilquiza and Severino share similar species, while the value close to 0 shows that very few species found in Rio Blanco are also found in the other two localities (Fig. 1).

\section{Activity record of ants in the hives}

Solenopsis sp. invaded a dying hive (few individuals and low performance of their queens), until completely displacing the bees. Solenopsis anthills were observed near the hives, but individuals of this species were rarely found in the remaining hives.

Camponotus mus, C. substitutus and C. punctulatus were recorded repeatedly nesting in "strong" beehives, with the presence of numerous ants (more than a hundred individuals, including adults, larvae, pupae and eggs). The bees and ants of these species did not interact or attack each other. The presence of these Formicidae did not disturb the normal functioning of the hives.

Pheidole sp., Acromyrmex hispidus and Crematogaster sp. were frequently found prowling the hives without nesting inside (attracted by bee honey). Therefore, they were considered temporary visitors to the hives, but with no disturbance to the bees. 
Table 3. Presence (+) and absence (-) of hand-collected ant species inside hives in apiaries at Severino, Tilquiza and Rio Blanco localities. Jujuy, Argentina.

\begin{tabular}{lccc}
\hline Locality & Severino & Tilquiza & Rio Blanco \\
Species & & & \\
\hline Myrmicinae & & + & - \\
$\quad$ Pheidole sp. & + & + & - \\
Solenopsis sp. & + & - & - \\
Acromyrmex hispidus & + & + & - \\
$\quad$ Crematogaster sp. & & & + \\
Dolichoderinae & - & & \\
$\quad$ Linepithema humile & & & + \\
Ponerinae & & + & - \\
Formicinae & + & + & - \\
$\quad$ Camponotus mus & + & - & \\
Camponotus punctulatus & + & & \\
$\quad$ Camponotus substitutus & & & \\
\hline
\end{tabular}

Similarity

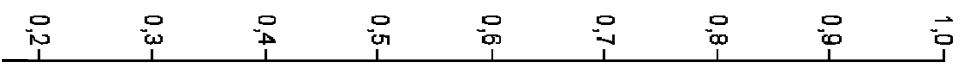

Rio Blanco

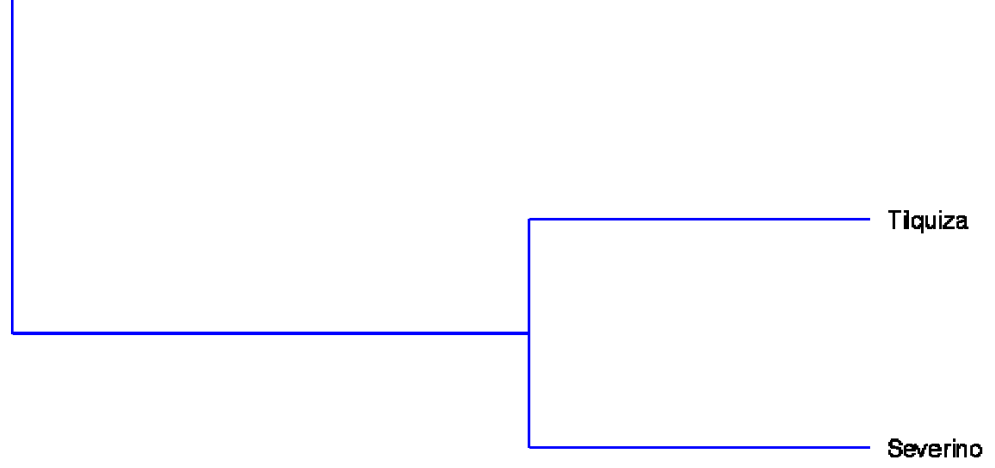

Fig. 1. Grouping of the localities under study in Jujuy, Argentina, using the Jaccard similarity coefficient of abundance in all sampling periods $(2016,2017$, and 2018).

Linepithema humile (Argentine ant) stole honey from the beehives analyzed. This was confirmed by the distension of its honey-laden gaster observed under stereoscopic magnifying glass. However, the number of individuals present was low (less than 20 ants), and did not cause losses in honey production. The good condition of the hives prevented their weakening and a negative impact on honey production.

\section{DISCUSSION}

A similar pattern to that observed for species diversity was also identified in terms of abundance. The data obtained on diversity allowed reporting on ant species related to honey bees at three localities in Jujuy, Argentina. This information is still unknown in most regions of the country (García et al., 2013). Regarding 
abundance, Tilquiza and Severino showed higher similarity indexes, while Río Blanco recorded the lowest value.

It is important to note that Río Blanco presents great agricultural activity, but also numerous industrial establishments, with native vegetation degraded by anthropic action (Carrillo and Londero, 2016). The dominance and dispersion of Linepithema humile is mainly due to urban development and vegetation degradation. It is a domestic pest that wipes out native ant species from places they invade. This would explain the dominance of this species, and the low diversity of other ant species in this locality (Ipinza-Regla et al., 2010; Jones et al., 2016). Severino and Tilquiza do not have important agricultural or industrial exploitation; apiaries are located in more forested areas away from and free from these activities.

Linepithema humile known as Argentine ant, is one of the most abundant and invasive species worldwide. In fact, it is found on all continents and many oceanic islands (Merrill et al., 2018), which indicates that the species is highly adaptable to urbanized sites and can displace other ant species from their nests. Its introduction is responsible for the decrease in the diversity and abundance of native ant species and other arthropods (Braun, 2001; Lach et al., 2010).

Severino and Tilquiza show great similarity in ant richness, while Río Blanco has a lower diversity. This difference in ant populations could be explained by the agricultural activities carried out in Rio Blanco as the reduction of native forest areas that might be directly affecting the insect fauna of the area (Carrillo and Londero, 2016).

Pitfall traps show that Camponotus punctulatus, Camponotus substitutus, Pseudomyrmex sp. were only present in Severino, with abundance levels of $7.28,3.4$ and $2.31 \%$, respectively. Camponotus mus was collected in all localities, and recorded a 5\% abundance level, whereas Pachycondyla constricta, Acromyrmex hispidus and Crematogaster $\mathrm{sp}$. were only collected in Severino and Tilquiza. Linepithema humile and Pheidole sp. were the ant species that were most abundantly found in the hives studied. These data coincide with those obtained by the research group that reported the presence of Linepithema humile in Río Blanco, and described that this ant species did not cause damage to strong and healthy hives with stored honey reserves (Dini y Bedascarrasbure, 2011; Benítez-Ahrendts et al., 2015; Ruiz and Benítez, 2018). Likewise, Pheidole sp. was found inside strong hives both in Severino and Tilquiza, causing no apparent damage.

Solenopsis sp. is one of the most abundant ant species in Tilquiza. It was observed that it carries larvae, pupae, adult bees and honey to their nests. There are studies that describe that this is an invasive and opportunistic species that likes to live close to or in weak and dying hives, forcing bees to migrate (Ruiz and Benítez, 2018; GISD, 2019).

According to the hand collections, they are frequent visitors to the Pheidole sp., Solenopsis sp., Linepithema humile and Camponotus mus hives, species found in large numbers without causing damage to the hives; except by Solenopsis sp., Camponotus subtitutus, Camponotus punctulatus, Acromyrmex sp. and Crematogaster sp., which appeared in a low quantity and did not cause any damage.

In general, certain species of ants move inside the hives. Others, nest in the inner roof cover, a kind of removable ceiling that beekeepers use for the protection of thermal amplitudes. The heat generated by the hive warms the inner roof cover that generates an ideal environment for ants to nest in the rainy and winter seasons (Valega, 2016; Ruiz and Benítez, 2018). Another observed behavior was foraging since some species of ants obtained sugary substances (mature and immature honey) from the hives (EcuRed, 2017; GISD, 2019). In general, the presence of ants in the hives does not cause discomfort to bees (Ruiz and Benítez, 2018). This may suggest the existence of a mutualistic relationship between these two species. On this respect, bees were seen walking very close to ants on the inside cover of the roof of strong hives, with no observation of aggressive or antagonistic behavior between. It is important to note that ants have a defense mechanism in which formic acid is sprayed. Regarding pest management, beekeepers struggle against Varroa mites in their hives. The Varroa mite (Varroa destructor) is a widespread mite in our country and worldwide, which can weaken and kill honey bee colonies within months of infestation (Berdugo et al., 2010). One of the organic products used for its control is formic acid. It has been described that bees, like other species such as birds, use baths of this acid to eliminate mites from their bodies (Morozov, 2015). It would be interesting to repeat this study in the other seasons of the year (autumn and winter) and deepen the study of the ecology and behavior of each ant species in the apiaries.

\section{CONCLUSIONS}

It is concluded that ant species Linepithema humile, Camponotus mus, Camponotus subtitutus, Camponotus punctulatus, Pheidole sp., Solenopsis sp., Acromyrmex sp. and Crematogaster sp. are frequent visitors to hives. Pheidole sp., Solenopsis sp. and Linepithema humile were the most 
abundant species. Solenopsis sp. causes damage to bees in weak or dying hives. Linepithema humile, Camponotus mus, Camponotus subtitutus, Camponotus punctulatus, Pheidole sp., Acromyrmex sp. and Crematogaster sp. do not harm strong and healthy hives. The results obtained suggest that honey bees can be affected by ants depending mainly on the ant species and conditions of the hive (sick or depopulated). Well-maintained hives by beekeepers are hardly damaged by ants.

\section{ACKNOWLEDGMENTS}

The authors would like to thank all beekeepers of Cooperativa de Productores Apícolas de Jujuy Ltda. (COPAJ) for their collaboration and support in allowing the inspection of their hives.

\section{LITERATURE CITED}

Anglada, M., A. Saluso, O. Ermácora, A. Maidana, D. Dans, y C. Decuyper. 2013. Hormigas podadoras: Estudios bioecológicos y alternativas de manejo en sistemas agrícolas y vegetación de monte en Entre Ríos. Universidad Nacional de Entre Ríos. Ciencia, Docencia y Tecnología Suplemento 3:1-19.

Benítez-Ahrendts, M., Cabana, M.J., Cruz, M.S., Durán, A.G., Huarachi, S., Retamoso, R., et al. 2015. Guía teórico práctica para pequeños productores apícolas. UNJu, San Salvador de Jujuy, Argentina.

Berdugo, R.J., R.J. Vivas, y M.L. Mex. 2010. Diagnóstico y control orgánico del ácaro Varroa (Varroa destructor) en el trópico. Instituto Nacional de Investigaciones Forestales, Agrícolas y Pecuarias, Campo Experimental Mocochá, Centro Regional del Sureste, Yucatán, México.

Blaimer, B.B. 2012a. Taxonomy and species-groups of the subgenus Crematogaster (Orthocrema) in the Malagasy region (Hymenoptera, Formicidae). ZooKeys 199:23-70.

Blaimer, B.B. 2012b. Una revisión subgenérica de Crematogaster y discusión de grupos regionales de especies (Hymenoptera: Formicidae). Zootaxa 3482:47-67.

Braun, W. 2001. Carta de aptitud ambiental de la provincia de Jujuy (Escala 1: 250.000). Departamento de Suelos y Ecología. Facultad de Ciencias Agrarias, Universidad Nacional de Jujuy, Jujuy, Argentina.

Buitrago, L.G. 1999. El clima de la Provincia de Jujuy. Cátedra de Climatología y Fenología Agrícolas. 2da ed. Facultad de Ciencias Agrarias, Universidad Nacional de Jujuy, Jujuy, Argentina.
Cabrera, A. 1982. Vegetación de la Provincia de Jujuy. Anales de la Academia Nacional de Agronomía y Veterinaria (ANAV). San Salvador de Jujuy, Argentina.

Carmona, V. y T. Carmona. 2013. La diversidad de los análisis de diversidad. Bioma (Chile) 14:20-28.

Carrillo, I.C., y M. Londero. 2016. Voluntariado Universitario en Rio Blanco, Jujuy, Argentina: Conocer, Intervenir y Crecer. 61-74. En Actas Congreso Internacional de Geografía - 77은 Semana de la Geografía, San Miguel de Tucumán, Argentina, 21-24 de septiembre. GAEA, Buenos Aires, Argentina.

Culebra-Mason, M.S., C. Sgarbi, P. Catalano, D. Blondel, F. Verzero-Villalba, y M. Ricci. 2009. Identificación de especies de Formicidos presentes en un cultivo de soja. XIII Jornadas Fitosanitarias Argentinas. 30 de septiembre y 1-2 de octubre. Termas de Rio Hondo, Facultad de Ciencias Forestales, UNSE, Santiago del Estero, Argentina.

Di Rienzo, J.A., F. Casanoves, M.G. Balzarini, L. Gonzalez, M. Tablada, y C.W. Robledo. 2015. Grupo InfoStat, FCA, Universidad Nacional de Córdoba, Argentina. Disponible en http:// www.infostat.com.ar (Consulta 5 de Abril 2019).

Dini, C., y E. Bedascarrasbure. 2011. Manual de apicultura para ambientes subtropicales: Una propuesta de la Red de Escuelas del Noroeste Argentino. INTA, Ciudad Autónoma de Buenos Aires, Argentina.

EcuRed. 2017. Enciclopedia Cubana Colaborativa. Conocimiento con todos y para todos. Hormiga Carpintera (Camponotus spp.). Disponible en https://www.ecured.cu/ Hormiga_Carpintera (Consulta 08 mayo 2019).

Ferrari, C.A., R. Otero, y J.A. Collía. 2011. La apicultura argentina y sus regiones. Una visión panorámica. Rivolin Hnos. SRL, Buenos Aires, Argentina.

García-Martínez, M., D. Martínez-Tlapa, L. Quiroz-Robledo, y J. Valenzuela-González. 2013. Diversidad alfa y beta de los ensambles de hormigas en un paisaje montano de Veracruz. p. 67-74. En M. Vásquez-Bolaños, Castaño-Meneses G., Cisneros-Caballero A., Quiroz-Rocha G., Navarrete-Heredia, J. (eds.) FORMICIDAE DE MÉXICO. Instituto de Ecología, Cuerpo Académico de Zoología, Ciudad de México.

GISD. 2019. Perfil de la especie: Solenopsis invicta. Global Invasive Species Database (GISD). Disponible en http://www.iucngisd.org/gisd/ species.php?sc=77 (Consulta 6 noviembre 2019). 
Guzmán-Novoa, E., A. Correa-Benítez, L.G. Espinosa-Montano y G. Guzmán-Novoa. 2011. Colonización, impacto y control de las abejas melíferas africanizadas en México. Veterinaria México (México) 42(2):149-178.

Hammer, Ø., D.A.T. Harper, and P.D. Ryan. 2001. PAST: Paleontological Statistics Software Package for Education and Data Analysis. Paleontología Electrónica 4(1):9. Disponible en http://palaeo-electronica.org/2001_1/past/ issue1_01.htm (Consulta 20 agosto 2018).

Hosoishi, S. 2015. Revisión del grupo Crematogaster ranavalonae en Asia, con descripción de dos nuevas especies (Hymenoptera, Formicidae). Revista de Investigación de Himenópteros 42:63-92.

Ipinza-Regla, J. H., G. Figueroa, y I. Moreno. 1984. Iridomyrmex humilis (Formicidae) y su papel como posible vector de contaminación microbiana en industrias de alimentos. Folia Entomológica Mexicana 62:11-124.

Ipinza-Regla, J., L.R. Castro, R. Eissemann y M.A. Morales. 2010. Factores que influyen en la distribución de nidos de la hormiga argentina Linepithema humile Mayr (hymenoptera: formicidae), en un ecosistema de las estribaciones de la zona central de Chile. Entomología Neotropical 39(5):686-90.

Ipinza-Regla J., D. González, G. Figueroa. 2015. Hormiga argentina Linepithema humile Mayr, 1868 (Hymenoptera: Formicidae) y su rol como posible vector de contaminación microbiana en una lechería de cabras Capra hircus Linnaeus, 1758 (Artiodactyla: Bovidae). Archivos de medicina veterinaria 47(3):317323.

Jones, G., S.J. Fenwick, U. Lallu, and D. Fraser. 2016. Perceptions and impacts: An observational pilot study of the effects of argentine ants on honey bees in New Zealand. Perspective in Biosecurity Research Series (1):1-11.

Kusnesov, N. 1952. El género Camponotus en Argentina (Hymenoptera- Formicidae). Acta Zoologica Lilloana 12:183-252.

Lach, L., C.L. Parr, and K.L. Abo. 2010. Ant ecology. Oxford University Press, Oxford, United Kingdom.

Lattke, J. 2003. Subfamila Ponerinae. p. 271-276. En Fernández F. (ed.) Introducción a las Hormigas de la región Neotropical. Instituto de Investigación de Recursos Biológicos, Alexander Von Humboldt, Bogotá, Colombia.

Longino, J.T., and D.J. Cox. 2009. Pheidole bilimeki reconsidered (Hymenoptera: Formicidae). Zootaxa 1985:34-42.
Mackay, W.P., and E. Mackay. 2002. The ants of New Mexico (Hymenoptera: Formicidae). Edwin Mellen Press, Lewiston, NY. United Kingdom, United States of America.

Merrill K.C., C.L. Boser, C. Hanna, D.A. Holway, I. Naughton, D.H. Choe, et al. 2018. Argentine ant (Linepithema humile, Mayr) eradication efforts on San Clemente Island, California, USA. Western North American Naturalist 78(4):829-836. https:// doi.org/10.3398/064.078.0422

Moreno-Moreno, H., y R. Meza-Santacruz. 1970. Reconocimiento e identificación de algunas plagas en apiarios de clima medio del Departamento de Nariño. Tesis de grado Ingeniero Agrónomo. Facultad de Ciencias Agrícolas, Universidad de Nariño, Colombia.

Moreno, C.E. 2001. Métodos para medir la biodiversidad. Serie Manuales y Tesis SEA $1: 1-84$

Morozov, N.S. 2015. ¿Por qué las aves practican anting? Uspekhi Sovremennoi Biologii. 135:97-112.

Nobua-Behrmann B.E. 2014. Interacciones tróficas entre dos especies simpátricas de hormigas cortadoras y el ensamble de plantas en el Monte central. Tesis Doctoral en Biología. Facultad de Ciencias Exactas y Naturales. Universidad de Buenos Aires, Buenos Aires, Argentina.

Olivero,D.,R.Guerrero,yM.Escárraga.2009.Claves taxonómicas para las hormigas cazadoras (Hymenoptera: Formicidae: Ponerinae S.STR., Ectatomminae, Heteroponerinae) de la Sierra Nevada de Santa Marta, Colombia. Revista Intropica 4:17-28.

Ruiz, G.B., y M. Benítez. 2018. Registro de hormigas (Hymenoptera: Formicidae) presentes en apiarios de Apis mellifera L. de los Valles Templados de la provincia de Jujuy-Argentina. Journal of the Selva Andina Research Society 9:113-119.

Valega, O. 2016. Mil consejos de cómo matar una amiga. Mis amigas las hormigas, tan vapuleadas y tan útiles para el apicultor. Disponible en https://www.apiservices.biz/ es/articulos/ordenar-por-popularidad/1196mil-consejos-de-como-matar-una-amiga (Consulta 15 abril 2019).

Ward, P.S. 2017. Una revisión de los grupos de especies Pseudomyrmex ferrugineus y Pseudomyrmex goeldii: acacias y parientes (Hymenoptera: Formicidae). Zootaxa 4227: 524-542. doi: 10.11646/zootaxa.4227.4.3 